Tile Journal of Vitaminology 5, 111-116 $(1959)$

\title{
INHIBITION OF BRAIN GLUTAMIC DECARBOXYLASE BY RUNNING FIT-INDUCING SUBSTANCES ${ }^{1}$
}

\author{
YOSHITO NISHIZAWA, TEISUKE KODAMA AND TARO YAMANAKA \\ Department of Pediatrics, Faculty of Medicine, Osaka University, Fukushima, Osaka
}

Received April 16, 1959)

It has been reported previously that pyrimidine derivatives (1), such as 2-methyl4-amino-5-hydroxymethylpyrimidine (OMP), 2,5-dimethyl-4-aminopyrimidine (I), 2,6-dimethy 1-4-aminopyrimidine (II) and 2-methyl-4-aminopyrimidine (III) as well as carbonyl reagents (2), such as hydroxylamine, semicarbazide, thiosemicarbazide, isonicotinic hydrazide and benzoic hydrazide, induce the running fit. It was also reported that all these compounds were closely related to vitamin $\mathrm{B}_{6}$.

Mandokoro (3) has shown that brain glutamate is reduced in the OMPinduced running fit and Namba (4) has studied the two enzyme systems related to vitamin $\mathrm{B}_{6}$, i.e. the transaminase involving glutamate and glutamic decarboxylase from the standpoint of glutamate metabolism and reported that inhibition of glutamic decarboxylase occurred prior to the onset of the running fit, whereas no close relationship was found between the transaminase and the occurrence of the running fit.

Brain glutamic decarboxylase is the enzyme involving glutamic acid, which is present in amounts of over $150 \mathrm{mg}$ per $100 \mathrm{~g}$ of the brain (5), and $\gamma$-aminobutyric acid, the content of which is about $50 \mathrm{mg}$ per $100 \mathrm{~g} \mathrm{(6)}$ and this enzyme is specifically active only in the brain (7). It can therefore be assumed that this enzyme has an important role in the metabolism of the brain (8).

Comparative studies on the effect of various running fit-inducing agents and of convulsants on glutamic decarboxylase were carried out in order to clarify the relationship between the inhibition of this enzyme and the occurrence of the running fit. The results of the study are presented in this paper.

\section{EXPERIMENTAL}

Animals Male rats weighing 50-90 g were used.

Test Samples The test samples were the following 9 compounds. The dosages were determined from the experiments of Miyake (1), Kumagai (2) and Namba (3) and injection was made subcutaneously. Hydroxylamine has already been examined by Namba (4), but was repeated here for verification.

Experiments - The animals were injected with each agent and immedi-

\footnotetext{
${ }^{1}$ Studies on Substances of the Toxopyrimidine Group. VII.
} 


\begin{tabular}{lr|lr}
\multicolumn{1}{c}{ Agent } & Dose & \multicolumn{1}{c}{ Agent } & Dose \\
& $\mu g / g$ & & $\mu / g$ \\
2,5 -dimethyl-4- & 600 & Isonicotinic hydrazide & 700 \\
$\quad$ aminopyrimidine & 300 & Benzoic hydrazide & 200 \\
Hydroxylamine & 1000 & Strychnine & 2 \\
Semicarbazide & 700 & Cardiazol & 100 \\
Thiosemicarbazide & & Ammonium chloride & 800
\end{tabular}

ately after the onset of the seizure killed by decapitation. Namba (4) reported that the inhibition of glutamic decarboxylase was already apparent prior to the onset of the OMP-induced running fit and in order to clarify the time relationship between the enzyme inhibition and the onset of the running fit, some of the animals were sacrificed about 5 minutes before the onset of the seizure. It occurred very soon after injecting hydroxylamine, so that the pre-seizure experiment was omitted in this case.

The brain was removed as soon as possible after decapitation and homogenized with 5 times its volume of $\mathrm{pH} 6.6$ phosphate buffer under chilling. Determination was made by the Wingo-Awapara method (9). The results were corrected with the control values.

Determination of Glutamic Decarboxylase. The Warburg manometry was used as follows :

Main chamber: homogenate

$2.0 \mathrm{ml}$

Side bulb : L-glutamic acid $0.5 \mathrm{ml}$ (final concentration $0.06 \mathrm{M}$ )

Central well : $1 \mathrm{~N}_{2} \mathrm{SO}_{4}$

$0.3 \mathrm{ml}$

Reaction condition: $\mathrm{pH} 6.8,37.5^{\circ}, \mathrm{N}_{2}$

Reaction time: 60 minutes

Sulfuric acid was tipped in at the termination of the reaction and the total $\mathrm{CO}_{2}$ produced measured manometrically.

\section{RESULTS}

Control Group The glutamic decarboxylase activity was distributed centering around the average value of $50 \mu \mathrm{l}$ (Table I, Fig. 1) in agreement with the results of Wingo and Awapara (4) and of Roberts and Frankel (7).

TABLE I

Glutamic Decarboxylase Activity of Normal Brain

$\begin{array}{cccc}\text { No. of mouse } & \text { Body weight } & \text { Weight of brain } & \text { CO. evolved } \\ & g & g & \mu l \\ 1 & 67 & 1.03 & 59.0 \\ 2 & 67 & 1.02 & 54.3 \\ 3 & 73 & 1.09 & 52.3 \\ 4 & 68 & 0.95 & 48.3 \\ 5 & 81 & 0.98 & 45.1 \\ 6 & 62 & 1.03 & 44.2 \\ 7 & 66 & 1.12 & 43.1\end{array}$


2,5-Dimethyl-4-aminopyrimidine — The running fit became apparent about 20 minutes after injection and the glutamic decarboxylase activity at this time (Table II, Fig. 1) was reduced compared with the control (Table I, Fig. 1). The degree of reduction is similar to that reported by Namba (4) in the case of OMP.

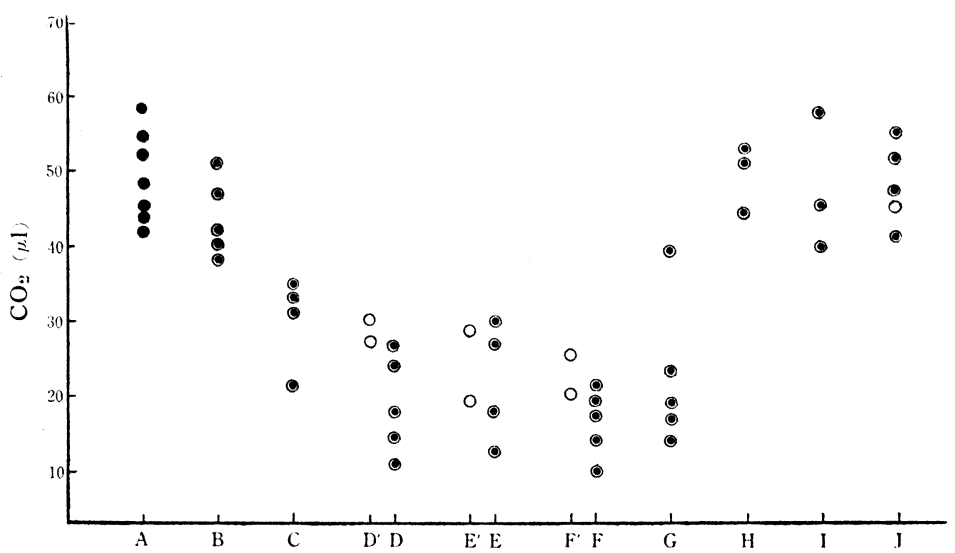

$\Lambda$, Control

$\mathrm{B}$, At the time of seizure following injection of $600 \mu \mathrm{g} / \mathrm{g}$ OMP

C, " " " " " $300 \mu \mathrm{g} / \mathrm{g}$ hydroxylamine

D, " " , " , " $1000 \mu \mathrm{g} / \mathrm{g}$ semicarbazide

$\mathrm{D}^{\prime}$, About $5 \mathrm{~min}$ prior to the injection of "

E, At the time of seizure following injection of $700 \mu \mathrm{g} / \mathrm{g}$ thiosemicarbazide

$\mathrm{E}^{\prime}$, About 5 min prior to the injection of "

$\mathrm{F}$, At the time of seizure following injection of $700 \mu \mathrm{g} / \mathrm{g}$ isonicotinic hydrazide

$\mathrm{F}^{\prime}$, About 5 min prior to the injection of

$\mathrm{G}$, At the time of seizure following injection of $200 \mu \mathrm{g} / \mathrm{g}$ benzoic hydrazide

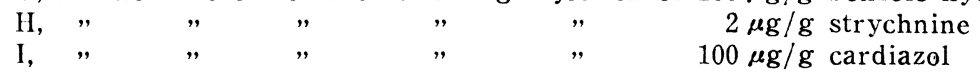

J, " " " " , " " $\quad 800 \mu \mathrm{g} / \mathrm{g} \mathrm{NH} \mathrm{NH}_{4} \mathrm{Cl}$

Fז' 2 Brain Glutamic Decarboxylase of Test Animals Following Injection of Test Samples

Hydroxylamine A severe seizure occurred about 5 minutes after injection. The glutamic decarboxylase activity at this time was clearly reduced (Table II, Fig. 1), compared with the control (Table I, Fig. 1). The results agree closely with those of Namba (4) using mice.

Semicarbazide About 80 minutes after injection, a marked running fit became apparent and the activity at this time was clearly reduced (Table II, Fig. 1) compared with the control. The reduction was already apparent 5 minutes before the onset of the seizure.

Thiosemicarbazide - The running fit occurred about 20 minutes after injection and the activity was clearly reduced (Table II, Fig. 1). In this case, too, the reduction was found ca. 5 minutes before the onset.

Isonicotinic Hydrazide A marked running fit became apparent about 40 minutes after injection and the activity at that time was clearly reduced 
TABLE II

Brain Glutamic Decarboxylase Activity Following Injection of Test Agents

\begin{tabular}{|c|c|c|c|c|c|}
\hline \multirow{2}{*}{ Agent (dose) } & \multirow{2}{*}{$\begin{array}{l}\text { No of } \\
\text { mouse }\end{array}$} & \multirow{2}{*}{$\begin{array}{l}\text { Body } \\
\text { weight }\end{array}$} & \multirow{2}{*}{$\begin{array}{l}\text { Weight } \\
\text { of brain }\end{array}$} & \multicolumn{2}{|c|}{$\mathrm{CO}_{2}$ evolved } \\
\hline & & & & $\begin{array}{c}\text { Before } \\
\text { (ca. } 5 \mathrm{~min} \text { ) }\end{array}$ & $\begin{array}{l}\text { During } \\
\text { seizure }\end{array}$ \\
\hline $\begin{array}{l}2,5 \text {-Dimethyl-4- } \\
\text { aminopyrimidine } \\
(600 \mu \mathrm{g} / \mathrm{g})\end{array}$ & $\begin{array}{l}1 \\
2 \\
3 \\
4 \\
5 \\
6 \\
7\end{array}$ & $\begin{array}{r}g \\
60 \\
65 \\
65 \\
53 \\
73 \\
63 \\
83\end{array}$ & $\begin{array}{c}g \\
1.09 \\
0.96 \\
0.91 \\
0.92 \\
1.04 \\
0.92 \\
0.97\end{array}$ & $\mu l$ & $\begin{array}{c}\mu l \\
42.9 \\
40.3 \\
30.4 \\
46.4 \\
41.0 \\
51.7 \\
38.3\end{array}$ \\
\hline $\begin{array}{l}\text { Hydroxylamine } \\
\qquad(300 \mu \mathrm{g} / \mathrm{g})\end{array}$ & $\begin{array}{l}1 \\
2 \\
3 \\
4\end{array}$ & $\begin{array}{l}82 \\
77 \\
57 \\
83\end{array}$ & $\begin{array}{l}0.95 \\
0.93 \\
1.00 \\
1.01\end{array}$ & & $\begin{array}{l}35.3 \\
33.5 \\
21.2 \\
36.2\end{array}$ \\
\hline $\begin{array}{l}\text { Semicarbazide } \\
\qquad(1000 \mu \mathrm{g} / \mathrm{g})\end{array}$ & $\begin{array}{l}1 \\
2 \\
3 \\
4 \\
5 \\
6 \\
7\end{array}$ & $\begin{array}{l}64 \\
54 \\
.59 \\
73 \\
64 \\
69 \\
85\end{array}$ & $\begin{array}{l}0.92 \\
1.14 \\
0.92 \\
1.00 \\
1.08 \\
1.07 \\
0.95\end{array}$ & $\begin{array}{l}25.8 \\
31.2\end{array}$ & $\begin{array}{l}15.2 \\
24.7 \\
11.4 \\
18.6 \\
22.7\end{array}$ \\
\hline $\begin{array}{l}\text { Thiosemicarbazide } \\
\qquad(700 \mu \mathrm{g} / \mathrm{g})\end{array}$ & $\begin{array}{l}1 \\
2 \\
3 \\
4 \\
5 \\
6\end{array}$ & $\begin{array}{l}65 \\
54 \\
82 \\
57 \\
76 \\
54\end{array}$ & $\begin{array}{l}0.86 \\
1.08 \\
1.03 \\
0.90 \\
1.08 \\
1.02\end{array}$ & $\begin{array}{l}28.3 \\
20.9\end{array}$ & $\begin{array}{l}16.0 \\
29.3 \\
30.9 \\
14.9\end{array}$ \\
\hline $\begin{array}{l}\text { Isonicotinic hydrazide } \\
\qquad(700 \mu \mathrm{g} / \mathrm{g})\end{array}$ & $\begin{array}{l}1 \\
2 \\
3 \\
4 \\
5 \\
6 \\
7\end{array}$ & $\begin{array}{l}52 \\
90 \\
60 \\
78 \\
70 \\
68 \\
85\end{array}$ & $\begin{array}{l}0.97 \\
1.03 \\
0.92 \\
1.01 \\
1.04 \\
0.97 \\
1.06\end{array}$ & $\begin{array}{l}26.8 \\
21.5\end{array}$ & $\begin{array}{l}22.4 \\
20.7 \\
16.1 \\
22.2 \\
12.4\end{array}$ \\
\hline $\begin{array}{l}\text { Benzoic hydrazide } \\
\qquad(200 \mu \mathrm{g} / \mathrm{g})\end{array}$ & $\begin{array}{l}1 \\
2 \\
3 \\
4 \\
5\end{array}$ & $\begin{array}{l}75 \\
70 \\
67 \\
79 \\
87\end{array}$ & $\begin{array}{l}0.92 \\
0.82 \\
0.97 \\
1.03 \\
1.22\end{array}$ & & $\begin{array}{l}16.8 \\
24.0 \\
19.0 \\
18.7 \\
38.5\end{array}$ \\
\hline $\begin{array}{l}\text { Strychnine } \\
\qquad(2 \mu \mathrm{g} / \mathrm{g})\end{array}$ & $\begin{array}{l}1 \\
2 \\
3\end{array}$ & $\begin{array}{l}63 \\
80 \\
68\end{array}$ & $\begin{array}{l}1.01 \\
1.08 \\
1.03\end{array}$ & & $\begin{array}{l}44.5 \\
50.5 \\
51.0\end{array}$ \\
\hline $\begin{array}{l}\text { Cardiazol } \\
\qquad(100 \mu \mathrm{g} / \mathrm{g})\end{array}$ & $\begin{array}{l}1 \\
2 \\
3\end{array}$ & $\begin{array}{l}60 \\
70 \\
67\end{array}$ & $\begin{array}{l}1.02 \\
0.88 \\
0.94\end{array}$ & & $\begin{array}{l}44.9 \\
38.8 \\
58.3\end{array}$ \\
\hline $\begin{array}{l}\mathrm{NH}_{4} \mathrm{Cl} \\
\quad(800 \mu \mathrm{g} / \mathrm{g})\end{array}$ & $\begin{array}{l}1 \\
2 \\
3 \\
4 \\
5\end{array}$ & $\begin{array}{l}56 \\
48 \\
58 \\
62 \\
86\end{array}$ & $\begin{array}{l}1.01 \\
1.00 \\
1.03 \\
0.95 \\
0.94\end{array}$ & & $\begin{array}{l}47.9 \\
57.6 \\
52.3 \\
47.1 \\
43.6\end{array}$ \\
\hline
\end{tabular}


(Table II, Fig. 1) compared with the control. The reduction was apparent ca. 5 minutes prior to the onset in this case, too.

Benzoic hydrazide - A jumping fit occurred about 30 minutes after injection and the activity was clearly reduced (Table II, Fig. 1) compared with the control.

Strychnine A very light, clonic convulsion took place about 10 minutes after injection, immediately followed by severe tonic convulsions. The glutamic decarboxylase activity at the time of the tonic convulsions showed little difference compared with the control (Table II, Fig. 1).

Cardiazol A light, clonic convulsion occurred about 5 minutes after injection, followed by tonic convulsions. There was little difference in activity compared with the control.

Ammonium Chloride Light, clonic convulsions became apparent about 10 minutes after injection, followed by tonic convulsions. There was scarcely any difference in activity compared with the control in this case, too.

\section{DISCUSSION}

Miyake (1) and Kumagai (2) have studied the running fit-inducing action of various agents, e.g., carbonyl reagents, and $\mathrm{OMP}$ analogues, and their relation to vitamin $B_{6}$. In this experiment, it has been shown that all of these running fit-inducing agents inhibit brain glutamic decarboxylase activity without exception and that the inhibition occurs prior to the seizure and is not a result of the seizure.

Strychnine, cardiazol and ammonium chloride, which do not incite the running fit, did not affect this enzyme. This finding coincides with the observation of Jenney et al. (10) that the convulsions induced by strychnine, cardiazol, ammonium chloride or electric shock could not be prevented by vitamin $B_{6}$. The running fit-inducing agents therefore differ from other convulsants in that they specifically inhibit brain glutamic decarboxylase and it is suggested that this enzyme inhibition is closely related to the occurrence of the running fit.

The sites of high activity of glutamic decarboxylase in the brain, however, are the nucleus lenticularis and nucleus caudatus of the brain stem (11) and it has been reported that the running fit induced by isonicotinic hydrazide can be prevented by the sedatives which act on the brain stem (12). Preston (13, 14) has shown that when thiosemicarbazide is injected in the cat, abnormal brain waves first appear in the nucleus caudatus, followed by abnormal waves from the cerebral cortex together with the seizure.

The results of this series of experiments suggest that the sites of inhibition of brain glutamic decarboxylase by the running fit-inducing agents are the nucleus lenticularis and nucleus caudatus of the brain stem. From the standpoint of brain metabolism, the running fit-inducing agents are characterized by inhibition of glutamic decarboxylase and this inhibition is considered to be a causal factor of the running fit. 


\section{SUMMARY}

1. Running fit-inducing agents characteristically inhibit the activity of brain glutamic decarboxylase and this inhibition is closely related to the occurrence of the running fit.

2. The enzyme is not affected by convulsants, e.g., strychnine, cardiazol and ammonium chloride, which do not incite the running fit.

3. The inhibitory action of carbonyl reagents is stronger than that of OMP group substances.

4. The site of origin of the running fit was discussed.

\section{REFERENCES}

1. Nishizawa, Y., Kodama, T., and Miyake, M., J. Vitaminol. 4, 1 (1958).

2. Nishizawa, Y., Kodama, T., and Kumagai, T., ibid. 4, 138 (1958).

3. Mandokoro, Y., Vitamins 13, 161 (1957).

4. Nishizawa, Y., Kodama, T., and Namba, S., J. Vitaminol. 4, 264 (1958).

5. Waelsch, H., Advances in Protein Chemistry. 6, 301 (1951).

6. Awapara, J., J. Biol. Chem. 187, 35 (1950).

7. Roberts, E., and Frankel, S., ibid. 190, 505 (1951).

8. Weil-Malherbe, H., Metabolism and Function in Nervous Tissue. Biochem. Soc. Symp. 8, 16 (1952).

9. Wingo, W., and Awapara, J., J. Biol. Chem. 187, 256 (1950).

10. Jenney, E.H., Smith R.P., and Pfeiffer, C.C., Fed. Proc. 12, 333 (1953).

11. Okumura, N., Seitai-no-Kagaku 5, 247 (1954).

12. Sasaki, T., Vitamins 6, 413 (1953).

13. Preston, J.B., J. Pharm. Exptl. Therap. 115, 28 (1955).

14. Preston, J.B., ibid. 115, 39 (1955). 